\title{
Faktor-Faktor Kesediaan Untuk Membayar Beras Kemasan Pada Pasar Swalayan
}

\section{Factors of Willingness to Pay Packaging Rice in the Swalayan Market}

\section{Ismalia Afriani*', Ainul Mardliyah, dan Supriyadi}

${ }^{1}$ STIPER Dharma Wacana Metro Jln. Kenanga No. 3 Mulyojati Metro

*E-mail : ismalia_stiper@yahoo.com

\begin{abstract}
The Change of people's shopping preference from traditional markets to shopping centers and modern markets are strongly facilitated by the development of modern markets (small, medium and large retail). This condition contributes the increasingly marketing of labeled packaged rice which offered by the modern market. The purpose of this study is to determine the factors that influence consumers' willingness to pay for packaged rice at supermarkets. The study was conducted for 4 months in June - September in the City of Bandar Lampung, Lampung Province, using the survey method. The research location was chosen purposively, at the Chandra supermarket and Giant Bandar Lampung. The sampling method used in this study is judgment sampling. The method of analysis has done using logistic regression analysis. The results showed that the factors that influence willingness to pay are bidding price, income and comfort factors. The highest value of odds ratio is owned by income factor which means that consumers who have higher income have the opportunity to buy packaged rice at supermarkets
\end{abstract}

Keywords: packaging rice, supermarkets, willingness to pay

Disubmit : 12 Januari 2019; Diterim : 24 Februari 2019; Disetujui : 25 April 2019

\section{PENDAHULUAN}

Beras merupakan komoditi strategis Indonesia ditinjau dari aspek ekonomi, sosial dan politik. Hal ini antara lain karena beras merupakan makanan pokok hampir semua peduduk Indonesia. Hampir seluruh beras yang diproduksi di Indonesia digunakan di dalam negeri guna memenuhi kebutuhan konsumsi penduduk $(96,7 \%$ dari total produksi). Sebagian beras yang diperdagangkan di pasar tradisional merupakan beras yang dijual dalam bentuk curah (per kilogram atau per liter), hanya sebagian kecil yang dibeli dalam bentuk kemasan berlabel.

Kebutuhan akan beras bermutu tinggi khususnya untuk memasok kebutuhan hotel dan restoran seluruh Indonesia, telah menimbulkan desakan para pelaku pasar beras nasional terhadap pemerintah untuk dapat segera memenuhi kebutuhan beras dengan mutu tinggi dari produksi dalam negeri (World Bank, 2007). Kondisi ini semakin merangsang pengusaha/pedagang beras untuk bersaing dengan menonjolkan varietas padi lokal dengan keunggulan sifatnya sebagai merk dagang atau label beras.

Pesatnya perkembangan pasar modern (ritel kecil, menengah dan besar) cukup memberikan andil dalam peningkatan pemasaran beras kemasan berlabel. Hasil studi Nielsen, (2010) dan Rusham, (2016) menunjukkan bahwa pangsa pasar modern cenderung mengalami peningkatan cukup nyata, sementara jumlah maupun pangsa pasar tradisional justru mengalami penurunan, meskipun masih memiliki peluang untung bersaing dengan pasar modern (Indiastuti, et,all 2008). Perubahan tersebut didorong oleh adanya perubahan trend konsumen atau preferensi masyarakat dalam berbelanja beras berlabel kearah pasar modern.

Banyak faktor yang mendorong perubahan preferensi berbelanja masyarakat dari pasar tradisional ke pusat perbelanjaan dan pasar modern. Hal ini terjadi karena banyaknya keunggulan yang ditawarkan 
oleh pasar modern. Menurut Murti et al. (2010), lokasi pembelian (swalayan) menjadi faktor yang berperan dalam mempengaruhi konsumen untuk pembelian beras kemasan. Kenyamanan, keamanan, kecepatan layanan, kualitas barang, kebersihan, kerapian, produk yang lengkap dengan harga bersaing adalah contoh keunggulan yang dimiliki oleh pasar modern.

Hasil penelitian Eviyati dan Wahyuni, (2015) menunjukkan margin pemasaran pedagang pasar swalayan sebesar Rp 275/kg lebih besar $600 \%$ jika dibandingkan margin pasar tradisional yang hanya sebesar Rp 43,67. Selisih margin yang cukup besar ini mencerminkan perbedaan harga yang diterima oleh konsumen. Meskipun harga jual pasar swalayan yang lebih tinggi, tidak menurunkan minat untuk berbelanja di pasar swalayan. Dengan pergeseran pola berbelanja masyarakat, tuntutan zaman dan kesibukan sebagian warga masyarakat, mendorong tumbuhnya pasar swalayan yang menyediakan berbagai kebutuhan rumah tangga termasuk beras didalamnya, untuk itu menarik untuk dikaji sampai sejauh mana kesediaan membayar konsumen terhadap beras kemasan di pasar swalayan. Penelitian ini bertujuan untuk menentukan faktorfaktor yang mempengaruhi kesediaan konsumen untuk membayar beras kemasan pada pasar swalayan, termasuk juga membayar mahal terhadap kenyamanan yang diterima dari penjualan pasar swalayan. Penelitian ini menekankan pada faktor-faktor sosial ekonomi yang mendorong kesediaan konsumen untuk membayar.

\section{METODE PENELITIAN}

Penelitian ini dilaksanakan selama 4 bulan pada bulan Juni - September 2017 di Kota Bandar Lampung Provinsi Lampung, dengan menggunakan metode survei. Lokasi penelitian dipilih secara purposive yaitu pasar swalayan Chandra dan Giant Bandar Lampung. Metode pengambilan sampel yang digunakan pada penelitian ini adalah judgement sampling. Metode ini merupakan teknik pengambilan sampel dari suatu populasi yang diharapkan dapat memenuhi tujuan riset, sehingga keterwakilannya terhadap populasi dapat dipertanggungjawabkan (Flowerdew, R., 2013). Pengambilan sampel dilakukan dengan cara peneliti berada di tempat penelitian untuk melakukan penyebaran kuisioner ataupun wawancara pada sampel konsumen yang membeli beras kemasan di pasar swalayan yang ditentukan. Jumlah sampel sebanyak 45 orang, dengan 3 kategori bid price dan masing-masing sampel terhadap bidding price sebanyak 15 orang.

Metode analisis menggunakan model persamaan regresi logistik untuk dapat menjelaskan hubungan antara $\mathrm{X}$ dan $\pi(\mathrm{x})$ yang bersifat tidak linear, ketidaknormalan sebaran dari $\mathrm{Y}$, keragaman respon yang tidak konstan dan tidak dapat dijelaskan oleh model regresi linear biasa (Agresti, 2010). Metode regresi logistik adalah suatu metode analisis statistika yang mendeskripsikan hubungan antara peubah respon yang memiliki dua kategori atau lebih dengan satu atau lebih peubah penjelas berskala kategori atau interval (Cole, 2007).

Jika data hasil pengamatan memiliki p peubah bebas yaitu x1, x2, x3, ., xp dengan peubah respon $Y$, dengan $\mathrm{Y}$ mempunyai dua kemungkinan nilai 0 dan $1, \mathrm{Y}=1$ menyatakan bahwa respon memiliki kriteria yang ditentukan dan sebaliknya $\mathrm{Y}=0$ tidak memiliki kriteria, maka peubah respon $\mathrm{Y}$ mengikuti sebaran Bernoulli dengan parameter $\pi$ (xi) sehingga fungsi sebaran peluang :

$\left.f(y i)=\left[\pi\left(x_{i}\right)\right]^{y i}\left[1-\pi\left(x_{i}\right)\right\}^{1-y i}\right], y_{i}=0,1$

Model umum regresi logistik dengan $\mathrm{p}$ peubah penjelas yaitu

$\Pi(\mathrm{x})=\underline{\exp (\mathrm{g}(\mathrm{x}))}$

$1+\exp (\mathrm{g}(\mathrm{x}))$

Dengan melakukan transformasi logit diperoleh

$\mathrm{g}(\mathrm{x})=\beta_{0}+\beta_{1} X_{1}+\ldots+\beta_{p} X_{p}, g(x)$ 
Merupakan penduga logit yang berperan sebagai fungsi linear dari peubah penjelas. Karena fungsi penghubung yang digunakan adalah fungsi penghubung logit maka sebaran peluang yang digunakan disebut sebaran logistik.

Untuk menentukan dan menganalisis besarnya nilai keinginan membayar (WTP) konsumen terhadap beras kemasan pada pasar swalayan, perlu ditentukan variabel-variabel yang akan dimasukkan ke dalam model untuk mengetahui faktor-faktor yang mempengaruhi besaran WTP masyarakat terhadap pembelian beras kemasan pada pasar swalayan. Beberapa variabel yang akan dimasukkan ke dalam model yaitu:

Bidding Price. Variabel bid berpengaruh penting karena nilai bid menentukan apakah masyarakat bersedia atau tidak membayar nilai bid yang ditawarkan. Asumsi yang berlaku adalah semakin tinggi nilai bid maka peluang menjawab tidak setuju semakin tinggi. 3 kategori bid price yaitu 1) Rp 9.000/kg, 2) Rp $12.000 / \mathrm{kg}, 3) \mathrm{Rp} 15.000 / \mathrm{kg}$

Usia. Variabel usia diduga berpengaruh dimasukkan ke dalam variabel karenaada kecenderungan, rumah tangga muda lebih memilih untuk berbelanja di swalayan karena kepraktisan dan gaya hidup .

Pendidikan. Variabel pendidikan dipertimbangan berpengaruh, karena dengan pendidikan yang tinggi maka akan mempengaruhi cara berbelanja konsumen.

Pendapatan. Pendapatan keluarga atau total pendapatan dalam satu rumah tangga sangat berpengaruh pada jumlah WTP yang ingin dikeluarkan untuk membeli beras kemasan pada pasar swalayan. Hal ini berkaitan dengan kemampuan ekonomi masyarakat dalam membayar. Asumsi yang digunakan adalah semakin tinggi pendapatan maka semakin besar peluang masyarakat menjawab setuju untuk membayar.

Kualitas. Variabel kualitas barang yaitu penilaian responden akan beras kemasan yang dijual pada pasar swalayan. Responden yang menjawab kualitas beras berpengaruh adalah konsumen yang menganggap bahwa beras kemasan pada pasar swalayan lebih pulen, lembut dan memiliki ukuran yang utuh. Asumsi yang digunakan yaitu jika kualitas beras berpengaruh maka akan semakin besar peluang masyarakat menjawab setuju untuk membayar.

Promosi. Variabel promosi yaitu penilaian responden akan promosi yang dilakukan oleh pasar swalayan berupa potongan harga dan brosur penawaran. Responden yang menjawab promosi berpengaruh adalah konsumen yang menganggap bahwa promosi dapat mempengaruhi keputusannya untuk membeli beras kemasan pada pasar swalayan. Asumsi yang digunakan yaitu jika promosi berpengaruh maka akan semakin besar peluang masyarakat menjawab setuju untuk membayar.'

Kenyamanan. Variabel kenyamanan yaitu penilaian responden akan kenyamanan berbelanja beras kemasan dipasar swalayan. Responden yang menjawab kenyamanan berpengaruh adalah konsumen yang menganggap bahwa lokasi pasar swalayan yang nyaman, ber-AC, bersih dan timbangan yang akurat dapat mempengaruhi keputusannya untuk membeli beras kemasan pada pasar swalayan. Asumsi yang digunakan yaitu jika konsumen merasa nyaman (berpengaruh) maka akan semakin besar peluang masyarakat menjawab setuju untuk membayar.

Persamaan regresi logit untuk melihat besarnya kesediaan responden untuk membayar dan faktorfaktor yang mempengaruhinya adalah sebagai berikut:

\section{$\mathrm{Li}=\mathrm{Ln}\left(\mathrm{P}_{\mathrm{i}} / 1-\mathrm{P}_{\mathrm{i}}\right)=\beta \mathrm{o}+\beta_{1} \mathrm{BP}+\beta_{2} \mathrm{USIA}+\beta_{3} \mathrm{PDDKN}+\beta_{4} \mathrm{JAK}+\beta_{5}$ PENDPTN $+\beta_{6} \mathrm{KW}+\beta_{7} \mathrm{PRMS}+$}

$\beta_{8}$ CMFRT

$\begin{array}{ll}\text { Dimana: } & \\ \text { Li } & \text { : Peluang masyarakat bersedia atau tidak bersedia membayar } \\ \beta 0 & \text { : Intersep } \\ \beta 1-8 & : \text { Koefisien regresi } \\ \text { BP } & : \text { Bid (rupiah/Kg) } \\ \text { USIA } & : \text { Umur (tahun) } \\ \text { PDDKN } & : \text { Tingkat pendidikan (tahun) }\end{array}$




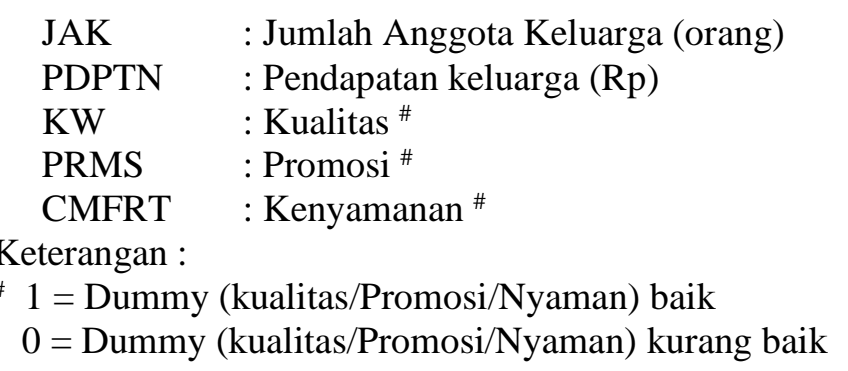

Pengujian terhadap parameter model dilakukan untuk memeriksa kebaikan model. Uji statistik yang dilakukan adalah dengan menggunakan statistik uji $G$ dan statistik uji Wald. Statistik uji G mengikuti sebaran chi-square $(\chi 2)$ dengan derajat bebas $p$. Kaidah keputusan yang diambil yaitu menolak $H_{0}$ jika

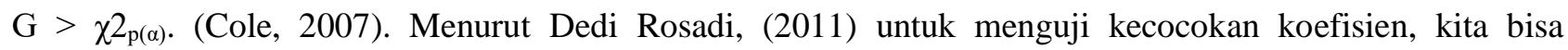
menggunakan uji Wald. Uji Wald merupakan uji univariat terhadap masing-masing koefisien regresi logistik (sering disebut partially test).

\section{HASIL DAN PEMBAHASAN}

Karakteristik Responden. Beberapa variabel yang digunakan sebagai pertimbangan dalam penelitian ini adalah umur responden, tingkat pendidikan, dan jumlah anggota keluarga. Umur responden diduga mempengaruhi minat pembelian beras pada pasar swalayan disebabkan perbedaan usia akan berpengaruh terhadap perbedaan selera dalam membeli dan mengkonsumsi suatu produk (Gambar 1).
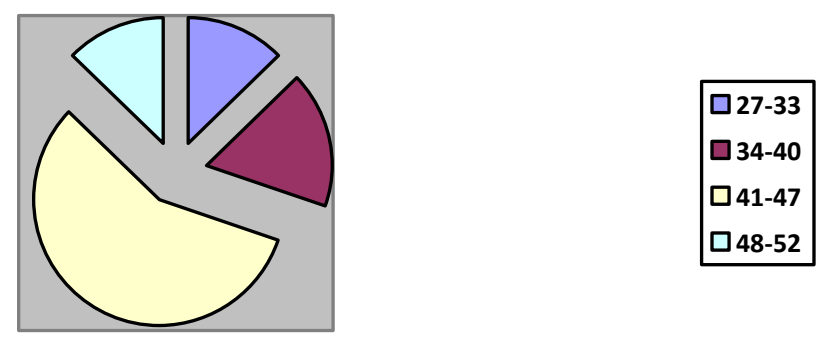

Gambar 1. Komposisi Sebaran Usia Responden

Gambar 1 terlihat bahwa konsumen beras kemasan sebagian besar 75,54\% berada pada kelompok umur < 40 tahun. Menurut Sumarwan, (2011) pada kelompok umur tersebut merupakan kelompok umur yang pada umumnya berfikir rasional dan praktis, dimana melakukan pembelian berdasarkan perhitungan waktu, biaya dan tenaga. Sedangkan sisanya $24,46 \%$ berada pada kelompok umur 41-52 tahun. Konsumen pada kelompok umur tua juga memiliki pertimbangan dalam membeli dan mengkonsumsi suatu barang dimana faktor kebiasaaan dan psikologis dalam berbelanja juga amat berperan, diantaranya jika sudah terbiasa dan merasa nyaman untuk berbelanja disuatu tempat maka akan sulit untuk merubah kebiasaaan tersebut .

Tingkat pendidikan responden sangat beragam pada kisaran SMA sampai pascasarjana, konsumen terbesar adalah pada lulusan sarjana sebanyak 73,33\% diikuti lulusan pascasarjana 22,22\% dan sisanya sebanyak 4,44 \% merupakan lulusan SMA (Gambar 2). Penelitian Sukarni et al. (2017), juga menunjukkan fenomena yang sama, bahwa konsumen yang berpendidikan tinggi lebih memilih sesuatu yang baru dan memiliki nilai inovasi. 

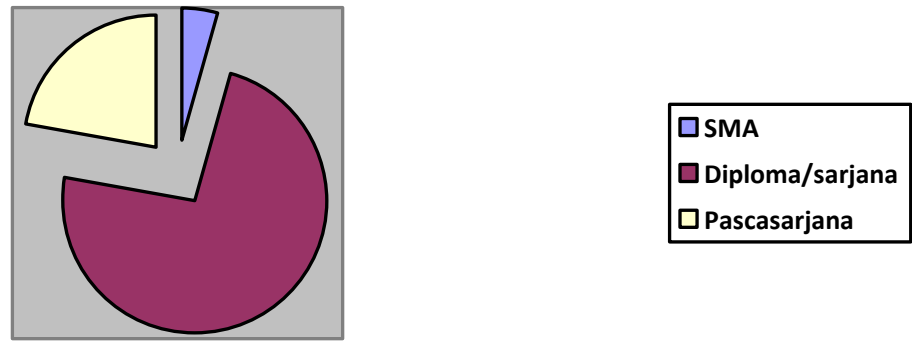

Gambar 2. Komposisi Sebaran Tingkat Pendidikan Responden

Konsumen dengan pendidikan cukup tinggi memiliki informasi dan pengetahuan yang cukup luas terhadap pembelian beras kemasan karena konsumen telah mengerti selisih harga dan praktis dalam berbelanja . Hal ini tentu akan mempengaruhi konsumen dalam proses pengambilan keputusan pembelian beras kemasan pada pasar swalayan.

Jumlah anggota keluarga merupakan salah satu faktor yang mempengaruhi proses keputusan pembelian, disebabkan berdampak terhadap beban yang ditanggung kepala keluarga, jika anggota keluarga semakin banyak maka semakin banyak pula pengeluaran keluarga (Gambar 3.) Selain itu Menurut Sumarwan, (2011) anggota keluarga dapat saling mempengaruhi dalam keputusan pembelian dan pengkonsumsian suatu produk. Beberapa peran anggota keluarga dalam pengambilan keputusan antara lain sebagai inisiator, pemberi pengaruh, penyaring informasi, pengambil keputusan, pembeli dan pengguna.
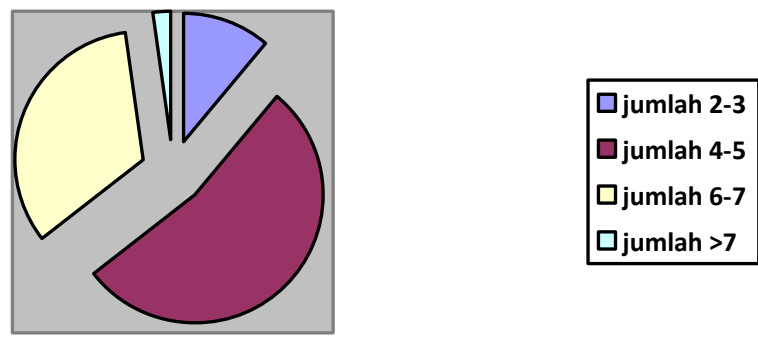

Gambar 3. Komposisi Sebaran Jumlah Anggota Keluarga

Rata-rata responden memiliki jumlah anggota keluarga yang beragam. Sebagian besar responden memiliki jumlah anggota keluarga sebanyak 4-5 orang sebesar 53,33\%. Hal ini akan mempengaruhi jumlah pembelian beras kemasan sebab semakin besar jumlah anggota keluarga maka semakin tinggi jumlah kebutuhan beras untuk konsumsi setiap anggota keluarga. Hanya 33,33\% jumlah anggota keluarga $6-7$ orang yang membeli beras pada pasar swalayan (Gambar 3).

Kualitas. Pertimbangan lain yang menjadi alasan untuk membeli pada pasar swalayan adalah adanya jaminan kualitas, bonus/promosi dan kenyamanan. Alasan promosi adalah alasan terbanyak pertama dengan jumlah responden 34 orang atau 75,56\%, promosi menjadi faktor yang penting juga didalam mempengaruhi konsumen untuk berbelanja (Kantohe and Karuntu, 2014). Alasan kenyamanan adalah alasan terbanyak kedua dengan jumlah responden 32 atau $71,11 \%$ sedangkan alasan kualitas yang terjamin merupakan alasan terakhir yang diungkapkan kenapa responden lebih memilih membeli beras kemasan pada pasar swalayan.

Faktor-Faktor Willingness To Pay Konsumen Beras Kemasan. Terkait dengan kesediaan masyarakat untuk membeli beras kemasan pada pasar swalayan, terdapat faktor atau penyebab yang mempengaruhi keputusan masyarakat untuk memberikan penilaian terhadap kesediaan. Dalam penelitian ini variabel respon yang digunakan adalah dalam bentuk pilihan bersedia atau tidak bersedia membeli beras kemasan pada pasar swalayan . Responden yang menjawab bersedia diberi nilai satu dan responden yang 
menjawab tidak diberi nilai nol. Terdapat tiga variabel bebas yang mempengaruhi kesediaan masyarakat untuk membeli beras kemasan pada pasar swalayan diantaranya nilai bid, pendapatan, dan kenyamanan. Faktor-faktor yang berpengaruh nyata ditentukan dengan menggunakan analisis regresi logistik. Hasil analisis faktor yang mempengaruhi dapat dilihat pada Tabel 1 .

Tabel 1. Hasil Analisis Faktor-faktor yang mempengaruhi kesediaan membeli beras kemasan pada pasar swalayan.

\begin{tabular}{llll}
\hline Parameter & Koefisien & Sig & Odds Ratio \\
\hline Konstanta & $-72,479$ & $0,072^{*}$ & 0,000 \\
Bidding Price & $-2,726$ & $0,024^{* *}$ & 0,065 \\
Usia & 8,689 & 0,330 & 5938,092 \\
Pendidikan & $-3,729$ & 0,723 & 0,024 \\
Jumlah Anggota Kelg & $-8,322$ & 0,132 & 0000 \\
Pendapatan & 11,450 & $0,059^{*}$ & 93900,608 \\
Kualitas & $-1,064$ & 0,854 & 0,345 \\
Promosi & $-0,252$ & 0,854 & 0,777 \\
Kenyamanan & 2,417 & $0,083^{*}$ & 11,214 \\
\hline
\end{tabular}

Log-Likelihood $=58,574$

Nagelkerne R Square $=0,617$

Goodness Of Fit Test

\begin{tabular}{llll}
\hline Method & Chi-Square & Df & $\boldsymbol{P}$ \\
\hline Omnibus Test & 26,849 & 8 & 0,001 \\
\hline Hosmer-Lemeshow & 2,838 & 7 & 0,900 \\
\hline
\end{tabular}

Sumber : Hasil Pengolahan Data Primer, 2017.

Keterangan:

** = Nyata Pada Taraf $5 \%$

* = Nyata Pada Taraf $10 \%$

Model regresi logit yang dihasilkan berdasarkan Tabel 1. adalah sebagai berikut:

$\mathrm{Li}=-72,479-2,726 \mathrm{BP}+8,689$ USIA - 3,729 PDDKN - 8,322 JAK + 11,450 PENDPT - 1,064 KW -

0,252 PRMS + 2,417 CMFRT

Tabel 1 menunjukkan bahwa hasil perhitungan analisis regresi logistik menampilkan statistik G, derajat bebas (df), dan P-Value. Hasil pengujian signifikansi regresi secara simultan didasarkan pada statistik uji G. Statistik uji G adalah pengujian hipotesis untuk melihat apakah semua koefisien faktor-faktor yaitu bidding price, usia, tingkat pendidikan, pendapatan, jumlah anggota keluarga, kualitas, promosi dan kenyamana sama dengan nol. Berdasarkan hasil log-likelihood sebesar -58,574 menghasilkan statistik G sebesar 26,849 dan P-Value bernilai 0.001 sehingga hipotesis nol harus ditolak yang berarti terdapat minimal satu slope model yang tidak sama dengan nol atau variabel bebas secara simultan berpengaruh nyata terhadap peluang menjawab setuju atau tidak setuju untuk membeli beras kemasan pada pasar swalayan sesuai bidding price yang ditawarkan pada taraf nyata $\alpha=1 \%$.

Uji kebaikan model dengan metode Hosmer-Lemeshow diperoleh nilai P Hosmer-Lemeshow sebesar 2,838. Nilai $\mathrm{P}$ yang diharapkan dari masing-masing metode adalah lebih besar dari 0.900 (menggunakan taraf nyata 10\%) karena hipotesis nolnya adalah model baik dalam mengepas data (model fit). Sehingga dapat disimpulkan bahwa model regresi yang dihasilkan cukup baik. Varibel bebas yang berpengaruh nyata terhadap model adalah bidding price, pendapatan, dan kenyamanan. Interpretasi tiap variabel bebas adalah sebagai berikut:

Bidding Price Variabel bidding price berpengaruh penting karena nilai bid menentukan apakah masyarakat bersedia atau tidak membayar harga yang ditawarkan. Koefisian bertanda negatif (-) yang berarti variabel bid berpengaruh negatif, semakin rendah nilai bid maka semakin besar peluang menjawab setuju. Variabel bid memilliki koefisien sebesar -2,726 artinya adalah kenaikan nilai bid sebesar Rp 1000 akan mempengaruhi peluang menjawab tidak setuju sebesar 27,6\%. Variabel bid memiliki P-Value sebesar 0.024 
yang menandakan variabel berpengaruh signifikan pada taraf nyata $\alpha=5 \%$. Nilai odds ratio variabel bid adalah 0,029 yang berarti nilai bid yang lebih rendah mempengaruhi responden untuk bersedia membayar WTP 0,029 kali lebih besar dibandingkan dengan nilai bid yang lebih tinggi.

Pendapatan. Pendapatan sangat berpengaruh pada jumlah WTP yang ingin dikeluarkan untuk membeli beras kemasan pada pasar swalayan. Hal ini berkaitan dengan kemampuan ekonomi masyarakat dalam membayar. Koefisien yang efisian bertanda positif (+) yang berarti variabel jumlah anggota keluarga berpengaruh positif. Variabel jumlah anggota keluarga memilliki koefisien sebesar 11,450 artinya adalah kenaikan pendapatan keluarga sebesar Rp 1.000.000 akan mempengaruhi peluang menjawab setuju sebesar $114,5 \%$. Variabel pendapatan memiliki P-Value sebesar 0.059 yang menandakan variabel berpengaruh signifikan pada taraf nyata $\alpha=10 \%$. Nilai odds ratio variabel pendapatan adalah 93900,608 yang berarti tingkat pendapatan yang lebih tinggi mempengaruhi responden untuk bersedia membayar WTP 93900,608 kali lebih besar dibandingkan dengan responden yang pendapatannya lebih rendah.

Promosi. Variabel promosi sebagian besar responden tertarik berbelanja di pasar swalayan karena tawaran promosi, promosi yang tepat akan meningkatkan minat beli konsumen (Swastha, 2011) begitu juga dengan kualitas. Pada penelitian ini kedua faktor tersebut tidak menjadi faktor yang menentukan, dikarenakan beberapa pasar swalayan yang menjadi objek penelitian tidak pernah memberikan promosi untuk jenis komoditas beras, sedangkan untuk kualitas, rata-rata konsumen merasa puas dengan kualitas beras dari pasar swalayan meskipun harus membayar lebih mahal.

Kenyamanan. Variabel kenyamanan yaitu penilaian responden akan rasa nyaman dalam berbelanja di pasar swalayan. Responden yang menjawab nyaman adalah responden yang lebih memilih berbelanja kebutuhan sehari-hari di pasar swalayan dibandingkan di pasar tradisional. Variabel kenyamanan merupakan variabel dummy dimana konsumen yang merasa nyaman diberi nilai satu sedangkan kondisi yang tidak setuju baik diberi nilai nol. Koefisien bertanda positif $(+)$ yang berarti variabel kenyamanan berpengaruh positif, apabila konsumen mersa nyaman, maka akan semakin besar peluang menjawab setuju untuk membayar WTP. Variabel kenyamanan memiliki koefisien sebesar 2,417 artinya apabila konsumen merasa nyaman maka peluang responden menjawab setuju untuk membayar WTP akan meningkat sebesar $24,1 \%$. Variabel kenyamanan memiliki P-Value sebesar 0.083 yang menandakan variabel berpengaruh signifikan pada taraf nyata $\alpha=10 \%$. Nilai odds ratio variabel kenyamanan adalah 11,214 yang berarti konsumen yang merasa nyaman mempengaruhi responden untuk bersedia membayar WTP 11,214 kali lebih besar dibandingkan dengan yang tidak setuju. Variabel kenyaman menjadi faktor utama bagi konsumen dalam memiliki lokasi berbelanja (Raharjani, 2005; Mufidah, 2006; Humaidi et al, 2015)

Variabel yang tidak berpengaruh signifikan terhadap kesediaan membayar adalah usia, tingkat pendidikan, jumlah anggota keluarga, kualitas dan promosi. Variabel usia dan pendidikan merupakan karakteristik sosial pada penelitian ini, dan tidak berpengaruh karena jika dilihat dari karakteristik responden lebih dari 70\% responden memiliki karakteristik yang sama berusia kurang dari 40 tahun dan berpendidikan sarjana. Dengan faktor usia responden yang cenderung berada pada masa dewasa madya (Hurlock, 2002) dan berpendidikan sarjana maka dapat lebih memilih praktis dan efisien (Dabholkar dan Bagozzi, 2002) mengingat mobilitas dan kesibukan yang tinggi, sehingga tidak memperhitungkan selisih harga antara pasar tradisional dan pasar modern.

\section{KESIMPULAN}

Keputusan untuk membeli beras kemasan pada pasar swalayan lebih dipengaruhi oleh, faktor bidding price, pendapatan dan kenyamanan. Nilai odds rasio paling tinggi dimiliki oleh faktor pendapatan yang berarti konsumen yang memiliki pendapatan yang lebih tinggi berpeluang untukmembeli beras kemasan pada pasar swalayan. Variabel pendapatan juga menjadi faktor yang sangat menentukan, karena pendapatan dapat menjadi ukuran kemampuan ekonomi dan kemampuan untuk membayar lebih beras kemasan yang dijual di pasar swalayan. 
Meskinpun variabel promosi memiliki persentase tertinggi sebesar $75 \%$ pada pilihan responden tetapi justru tidak berpengaruh nyata terhadap peluang membeli beras pada pasar swalayan ini disebabkan hampir secara keseluruhan swalayan/supermarket tidak memberikan promosi terhadap komoditas beras sehingga promosi bukan menjadi faktor penentu bagi faktor penjualan beras kemasan pada pasar swalayan.

Penjualan beras kemasan pada pasar swalayan sangat membantu para konsumen usia dewasa madya dengan penghasilan menengah yang memiliki kesibukan sehingga lebih praktis untuk berbelanja pada pasar swalayan daripada berkeliling di pasar tradisonal sehingga ini merupakan peluang bagi pasar swalayan untuk meningkatkan daya saing melalui harga dan kualitas barang yang tersedia. Disamping faktor kenyamanan yang sudah menjadi daya tarik tersendiri bagi pasar swalayan.

\section{DAFTAR PUSTAKA}

Agresti, A. 2010. Analysis of Ordinal Categorical Data, John Wiley \& Sons, INC. doi: $10.1002 / 9780470594001$.

Cole, T. J. 2007. 'Applied logistic regression. D. W. Hosmer and S. Lemeshow, Wiley, New York, 1989. No. of pages: xiii + 307. Price: £36.00', Statistics in Medicine, 10(7), pp. 1162-1163. doi: 10.1002/sim.4780100718.

Dedi Rosadi 2011. Analisis Ekonometrika \& Runtun Waktu Terapan dengan R. Yogyakarta.

Eviyati, R. and dan Siti Wahyuni 2015. 'Kepuasan Konsumen Terhadap Pemilihan Kualitas Dan Rasa Beras', Jurnal Agrijati, 28(1), pp. 1-19.

Flowerdew, R., dan D. M. 2013. Methods in Human Geography A guide for students doing a research project. 2nd Editio. London: Routledge Taylor and Francis. Available at: https://www.taylorfrancis.com/books/e/9781315837277.

Humaidi, E. and Amin, Zaini, N. S. .2015. 'Pola Pengeluaran Rumah Tangga Petani Karet Di Desa Binjai Kecamatan Muara Kelingi’, SOCIETA, IV(1), pp. 54-58.

Indiastuti, R., Hastuti, F. and Azis, Y. 2008. 'Analisis Keberlanjutan Pasar Tradisional dalam Iklim Persaingan Usaha yang Dinamis di Kota Bandung', Sosiohumaniora, 10(2), pp. 17-37.

Kantohe, J. and Karuntu, M. 2014. 'Faktor-Faktor yang Mempengaruhi Konsumen dalam Berbelanja pada Fiesta Pasar Swalayan Manado', Journal EMBA, 2(1), pp. 66-77.

Mufidah, N. L. 2006. 'Pola Konsumsi Masyarakat Perkotaan: Studi Deskriptif Pemanfaatan Foodcourt oleh Keluarga', Biokultur, (2), pp. 157-178. Available at: http://journal.unair.ac.id/filerPDF/05 jurnal nur lailatul----Pola pemanfaatan Foodcourt oleh Keluarga.pdf.

Nielsen, A. 2010. Laporan Pertumbuhan Ritel Modern dan Dampaknya terhadap Ritel Tradisional. Jakarta.

Raharjani, J. 2005. 'Keputusan, Mempengaruhi Pasar, Pemilihan Kasus, Studi Pasar, Pada Kawasan, Di Simpang, Seputar Semarang, Lima Raharjani, Jeni', Jurnal Studi Manajemen \& Organisasi, 2, pp. $1-15$.

Rusham, R. 2016. 'Analisis Dampak Pertumbuhan Pasar Moderen Terhadap Eksistensi Pasar Tradisional Di Kabupaten Bekasi', Ilmiah Ekonomi Manajemen Dan Kewirausahaan 'Optimal', 10(2), pp. 153166. 
Afriani, I., dkk : Faktor-Faktor Kesediaan Untuk Membayar Beras Kemasan Pada Pasar Swalayan

Sumarwan, U. 2011. Prilaku Konsumen. Edisi kedua. Bogor: Ghalia Indonesia.

World Bank . 2007. Horticultural Producers and Supermarket Development in Indonesia. Jakarta: The World Bank Office. 